\title{
Cancer-Specific Loss of Urocortin 3 in Human Renal Cancer
}

\author{
Pouriya Faraj Tabrizi - Anahit Mohebbi Tafrechi · Inga Peters · \\ Faranaz Atschekzei · Markus Antonius Kuczyk · Jürgen Serth • \\ Hossein Tezval
}

Received: July 15, 2019 / Published online: November 13, 2019

(C) The Author(s) 2019

\section{ABSTRACT}

Introduction: The corticotropin-releasing hormone (CRH) system, its receptors corticotropinreleasing hormone receptor 1 (CRHR1) and 2 (CRHR2), and its corresponding binding protein corticotropin-releasing hormone-binding protein (CRHBP) as well as the urocortin proteinsstructural homologues to $\mathrm{CRH}$, which are included in this peptide family-have become interesting oncological targets recently. Carcinogenesis of various human tumors has been reported with an altered presence of members of this system. The aim of the present study was to

Enhanced Digital Features To view enhanced digital features for this article go to https://doi.org/10.6084/ m9.figshare.10038032.

P. Faraj Tabrizi - I. Peters · M. A. Kuczyk · J. Serth · H. Tezval ( $\square)$

Department of Urology and Urological Oncology, Hannover Medical School, Hannover, Germany

e-mail: tezval.hossein@mh-hannover.de

\section{A. Mohebbi Tafrechi}

Department of Psychosomatic Medicine and

Psychotherapy, University Medicine Göttingen,

Göttingen, Germany

\section{F. Atschekzei}

Department of Clinical Immunology and

Rheumatology, Hannover Medical School,

Hannover, Germany examine the role of urocortin 3 (UCN3) in renal cell carcinoma (RCC).

Methods: Therefore, tumoral tissues of 106 patients with RCC and available corresponding normal tissues were analyzed using qPCR for quantitative mRNA expression analysis. Tissue localization and protein signals of UCN3 in normal and tumoral renal specimens were evaluated using western blot and immunohistochemistry. In addition, correlation studies of UCN3 mRNA expression with clinicopathological parameters of patients with RCC and different histological subtypes were evaluated.

Results: UCN3 mRNA was significantly downregulated in nearly all tumoral tissues $\left(p=7.92 \times 10^{-13}\right)$. The same effect was observed at protein level using immunohistochemistry. Level of UCN3 mRNA expression was not directly correlated with clinicopathological parameters.

Conclusion: We report for the first time the significant downregulation of UCN3 in RCC. These results demonstrate a possible involvement of the CRH system and its significance in carcinogenesis of RCC.

Keywords: Clear cell renal cell carcinoma; Corticotropin-releasing hormone; Kidney cancer; Urocortin; Urology 
Key Summary Points

This manuscript contributes to a better understanding of tumor metabolism in human renal cancer-a serious urological malignancy-and is of broad interest as it demonstrated new results which could possibly contribute to the development of new targeted therapies in oncology.

The direct influence of the corticotropinreleasing hormone $(\mathrm{CRH})$ axis in renal cancer vascularization has already been confirmed.

Our previous studies showed significant changes of members of the CRH system in human renal cancer on mRNA and protein level, e.g., UCN, CRHR2, CRHBP. In this study the role in human renal cancer of another member of the urocortin system-UCN3, a selective CRHR2 agonist-was investigated.

The almost complete loss of both protein and mRNA levels of UCN3 was observed in renal cancer. This could be an important mechanism in tumorigenesis.

On the other hand, a statistical correlation with clinical parameters, which represent disease progression, was not significant.

While some of the peptides of the CRH system are more involved in tumorigenesis, others seem to play remarkable roles in the progression of the disease.

We believe that in the near future members of the CRH system could be part of targeted therapies against kidney cancer, which is a solid cancer in humans, that is showing increasing incidence.

\section{INTRODUCTION}

The corticotropin-releasing hormone (CRH) pathway, primarily described as the major neuroendocrine pathway modulating stress- related response through the hypothalamic-pituitary-adrenal (HPA) axis, consists of $\mathrm{CRH}$, urocortin (UCN or UCN1), UCN2, and UCN3. These peptides act through activation of two G-protein-coupled receptors with different specificities and effects-CRHR1 and CRHR2. The corresponding binding protein CRHBP to which a regulatory function is attributed binds $\mathrm{CRH}$ analogues and serves as a ligand trap in the CRH system [1-7]. It has been shown that CRH analogues inhibit tumor growth via effects on angiogenesis by reduction of vascular endothelial growth factor (VEGF) synthesis and cell proliferation through activation of $\mathrm{CRH}$ receptors in different tumor entities, especially by activation of CRHR2 [8-11]. Expression and pathophysiological implication of the CRH pathway in several human cancers have been reviewed lately $[11,12]$. Recently, we reported the translocation of UCN and reduction of CRHR2 in clear cell renal cell carcinoma (ccRCC) [5]. UCN3 in human kidney and its presence in serum and urine have also been described, but with approximately 5-fold higher urine levels than that of plasma and higher urine levels compared to other vasoactive peptides found in urine. This supports the hypothesis of renal tubular cells as the origin of UCN3 $[2,4]$. Up to now, there are no comparable data available about the gene expression of UCN3 in RCC and its role in renal cancer biology, although alterations of other members of the CRH peptide family such as UCN, CRHBP, or CRHR2 have already been reported. Kaprara et al. reviewed literature showing that different tumor entities, e.g., prostate, thyroid, lung, breast, and gastrointestinal tumors, exhibit different expression patterns of members of the CRH system depending on tumor grading and staging [12]. Therefore, and in order to extend the understanding of the CRH peptide family and its influence on the tumor biology of RCC, another member of the CRH system, UCN3, was investigated in this study. We examined the expression of UCN3 in 106 human kidney specimens and available corresponding benign peritumoral specimens by qPCR analysis. Protein signals were examined by western blot analysis. Tissue localization was investigated by immunohistochemistry. 
Moreover, a statistical correlation analysis between mRNA expression of UCN3 in kidney cancer with clinicopathological parameters was performed.

\section{METHODS}

\section{Patients' Characteristics}

Tumor tissues of 106 patients subjected to kidney surgery between 2001 and 2005 collected from the Eberhard Karls University of Tuebingen were included in the present study. Tissue preparation, storage, pathological evaluation, tumor stage assessment, nuclear grading, and data management have been described previously [13]. The study was approved by the ethical committee of the Eberhard Karls University of Tuebingen (ethics votes number 128/2003V). All procedures performed in this study involving human participants were in accordance with the ethical standards of the institutional research committee and with the 1964 Helsinki declaration and its later amendments. Informed consent was obtained from all individual participants included in this study. Out of 106 patients in total, 77 patients with the histological subtype of ccRCC, 22 with the histological subtype of papillary renal cell carcinoma (pRCC), and available paired benign samples were considered in this study (Table 1) [14].

\section{RNA Isolation and qPCR Quantitation of Relative mRNA Expression Levels}

RNA isolation and qPCR have been described before [15]. Briefly, total RNA was reverse-transcribed into single-strand complementary DNA (cDNA) using the high capacity cDNA reverse transcription kit (Applied Biosystems, Foster City, CA, USA). Analysis of the results was performed in duplicate with an ABI 7900 Fast Sequence Detection System using TaqMan gene expression assays and Universal PCR Master Mix according to the manufacturer's protocol (Applied Biosystems, Foster City, CA, USA) as described before [15]. The TaqMan assays were UCN3 (Assay ID: Hs00846499_s1), GUSB (Assay
Table 1 Clinicopathological data of patients with RCC used in this study

\begin{tabular}{|c|c|c|}
\hline Clinicopathological parameters & $\begin{array}{l}\text { Number of } \\
\text { patients }\end{array}$ & $\%$ \\
\hline Total & 106 & 100 \\
\hline Age (mean \pm standard deviation) & $63 \pm 11.9$ & \\
\hline Male & 68 & 64.2 \\
\hline Female & 38 & 35.8 \\
\hline \multicolumn{3}{|l|}{ Histological subtype } \\
\hline Clear cell & 77 & 72.6 \\
\hline Papillary & 22 & 20.8 \\
\hline Mixed histology & 5 & 4.7 \\
\hline Other/not classified & 2 & 1.9 \\
\hline \multicolumn{3}{|l|}{ Staging } \\
\hline pT1a & 32 & 30.2 \\
\hline pTlb & 29 & 27.4 \\
\hline $\mathrm{pT} 2$ & 5 & 4.7 \\
\hline pT3a & 13 & 12.3 \\
\hline $\mathrm{pT} 3 \mathrm{~b} / \mathrm{c}$ & 24 & 22.6 \\
\hline pT4 & 0 & 0 \\
\hline Not classified & 3 & 2.8 \\
\hline $\begin{array}{l}\text { Synchronous lymph node } \\
\text { metastasis }\end{array}$ & 11 & 10.4 \\
\hline Synchronous distant metastasis & 23 & 21.7 \\
\hline $\begin{array}{l}\text { Advanced disease (pT3-4 and/or } \\
\mathrm{N}+/ \mathrm{M}+)\end{array}$ & 49 & 46.2 \\
\hline \multicolumn{3}{|l|}{ Grading } \\
\hline G1 & 17 & 16 \\
\hline G1-2 & 15 & 14.2 \\
\hline G2 & 57 & 53.8 \\
\hline G2-3 & 7 & 6.6 \\
\hline G3 & 10 & 9.4 \\
\hline
\end{tabular}

ID: Hs00939627_m1), RPL134 (Assay ID: Hs03043885_g1), and HPRT1 (Assay ID: Hs99999909_m1). The human GUSB, RPL134, 
and HPRT1 transcripts served as endogenous controls. Additionally, no template, no reverse transcription, and blank controls were conducted in each run.

Relative quantities of transcripts were calculated using the SDS 2.3 Manager data assist v2.0 software and the $2^{-\Delta \Delta \mathrm{Ct}}$ method as described before [15-17], but replacing the biological control by the average Ct values for UCN3 and the endogenous controls as obtained from the whole tissue sample group.

\section{Western Blot Analysis}

Western blotting was carried out according to standard protocols. Blot incubation was performed with primary rabbit antibody for UCN3 (1:400 dilutions; Sigma-Aldrich Co. LLC., St Louis, Missouri, USA). $\beta$-tubulin was used as a loading control. Further steps have been described earlier [14].

\section{Immunohistochemistry}

Immunohistochemical $(n=40)$ detection of UCN3 was performed with an anti-human UCN3 antibody-a polyclonal rabbit antibody (1:500 dilutions, H-019-28, Phoenix pharmaceuticals $\mathrm{GmbH}$, Karlsruhe, Germany). The paraffin-embedded tissue sections were demasked and stained with the Avidin/Biotin Blocking Kit (Vector Laboratories, Burlingame, CA, USA) as described before [5]. A negative control was conducted omitting the primary antibody. Corresponding benign kidney tissue served as a positive control [4].

\section{Statistical Analysis}

The paired $t$ test was applied for comparison of kidney tumor tissue and paired benign tissue. Univariate logistic regression models were carried out for independent group comparisons. Means and standard deviations (SD) per group, odds ratios (OR), corresponding 95\% confidence intervals (CI), and two-sided $p$ values are presented. $p<0.05$ was considered to be statistically significant.

\section{RESULTS}

\section{Expression of UCN3 in Normal Kidney and Kidney Cancer}

In most of the samples a relative loss of $U C N 3$ mRNA expression in corresponding tumor tissues as indicated by the negative differences of sorted pairwise relative expressions was detected. Group comparison of all RCCs and corresponding normal tissue samples showed a relative expression loss of UCN3 mRNA $\left(p=7.92 \times 10^{-13}\right.$; Fig. 1$)$.

Statistically significant lower expression of UCN3 could also be observed for ccRCC in comparison to normal kidney $\left(p=1.7 \times 10^{-10}\right.$; Fig. 2). However, even lower expression of UCN3 was observed in pRCC in comparison to $\operatorname{ccRCC}(p=0.042$; Fig. 3$)$.

\section{Western Blot Analysis}

Western blot analysis showed exemplarily a tumor-specific signal loss of the UCN3 protein in lane 1 (Fig. 4). $\beta$-tubulin, which even showed a stronger staining in the tumor lane (1) than in the normal tissue lane (2), was used as an internal control.

\section{UCN3 Protein Localization in Benign Renal Tissue and ccRCC}

Immunohistochemistry revealed the translation of UCN3 mRNA in normal kidney and showed its corresponding protein loss in ccRCC. UCN3positive immunostaining in normal kidney, shown mainly in distal tubules of renal cortex, has already been detected [4]. Here, no signal for UCN3 could be observed in ccRCC specimens (Fig. 5).

\section{Correlation with Clinicopathological Parameters}

No correlation between UCN3 expression in all examined tumor samples (all kidney tumors and ccRCC, separately and combined) and disease-free survival was observed $(p>0.05$, data 
A

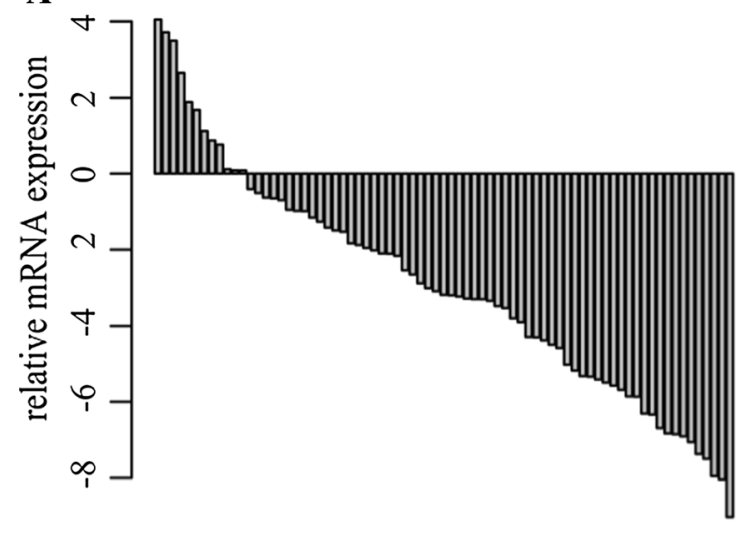

B

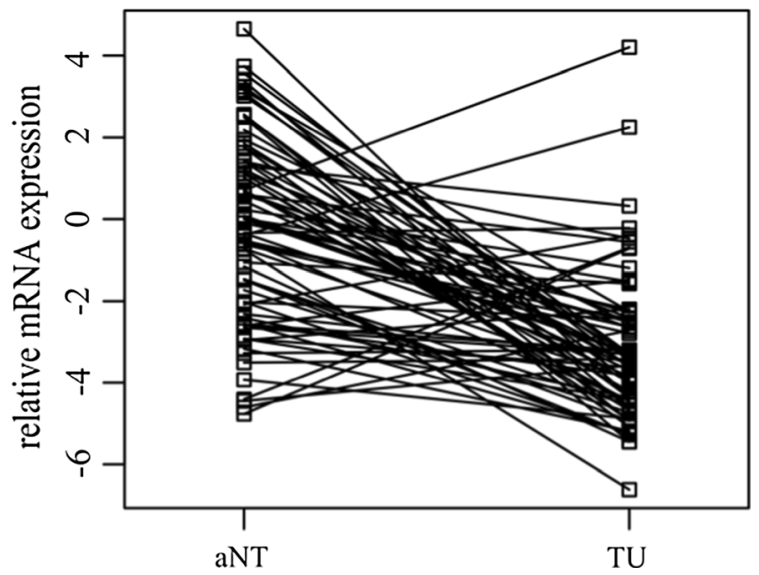

Fig. 1 Difference plot comparison of relative UCN3 mRNA expression levels of all RCCs (TU) and adjacent normal tissue samples (aNT) with logarithmic vertical scaling as measured by qPCR
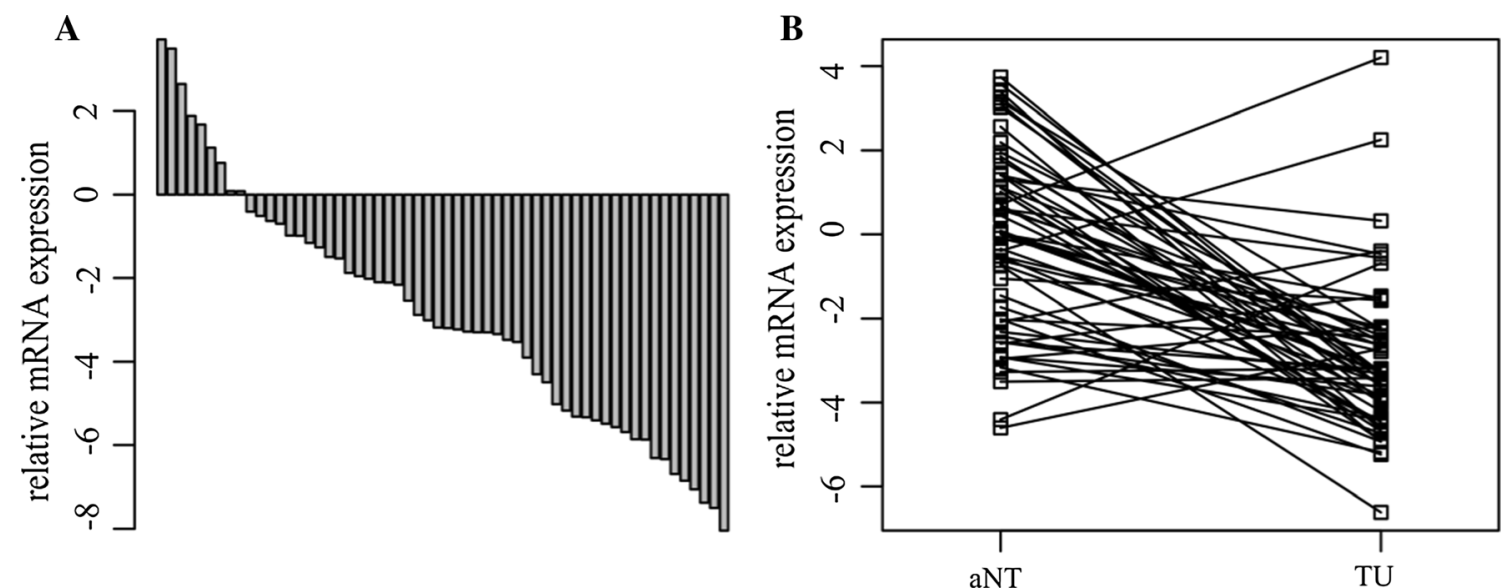

Fig. 2 Difference plot comparison of relative UCN3 mRNA expression levels of ccRCC (TU) and adjacent normal tissue samples (aNT) with logarithmic vertical scaling as measured by qPCR

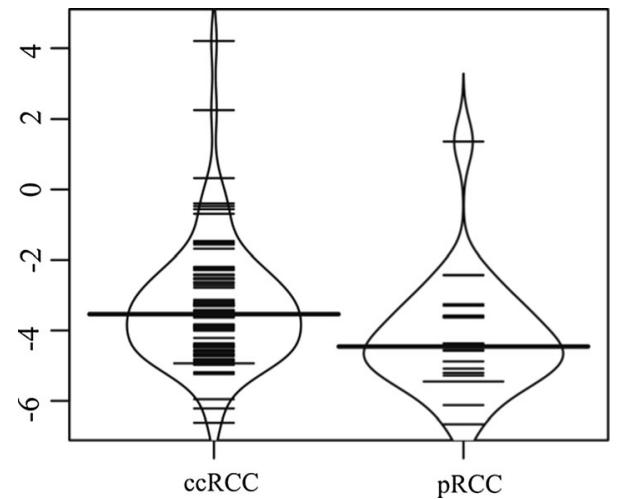

Fig. 3 Bean plot comparison of relative UCN3 mRNA expression levels of ccRCC and pRCC with logarithmic vertical scaling as measured by $\mathrm{qPCR}$

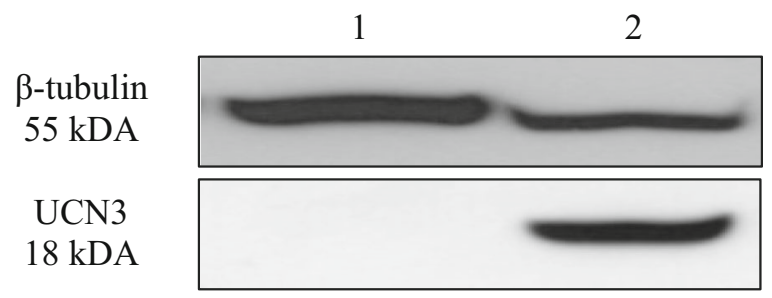

Fig. 4 Western blotting of UCN3 in renal tumor (1) and corresponding normal renal tissue (2). $\beta$-tubulin was used as an internal control. Lane 1 showed no protein signal for UCN3

not shown). Correlations with other clinicopathological parameters such as sex, age, lymph node metastasis, distant metastasis, staging, 

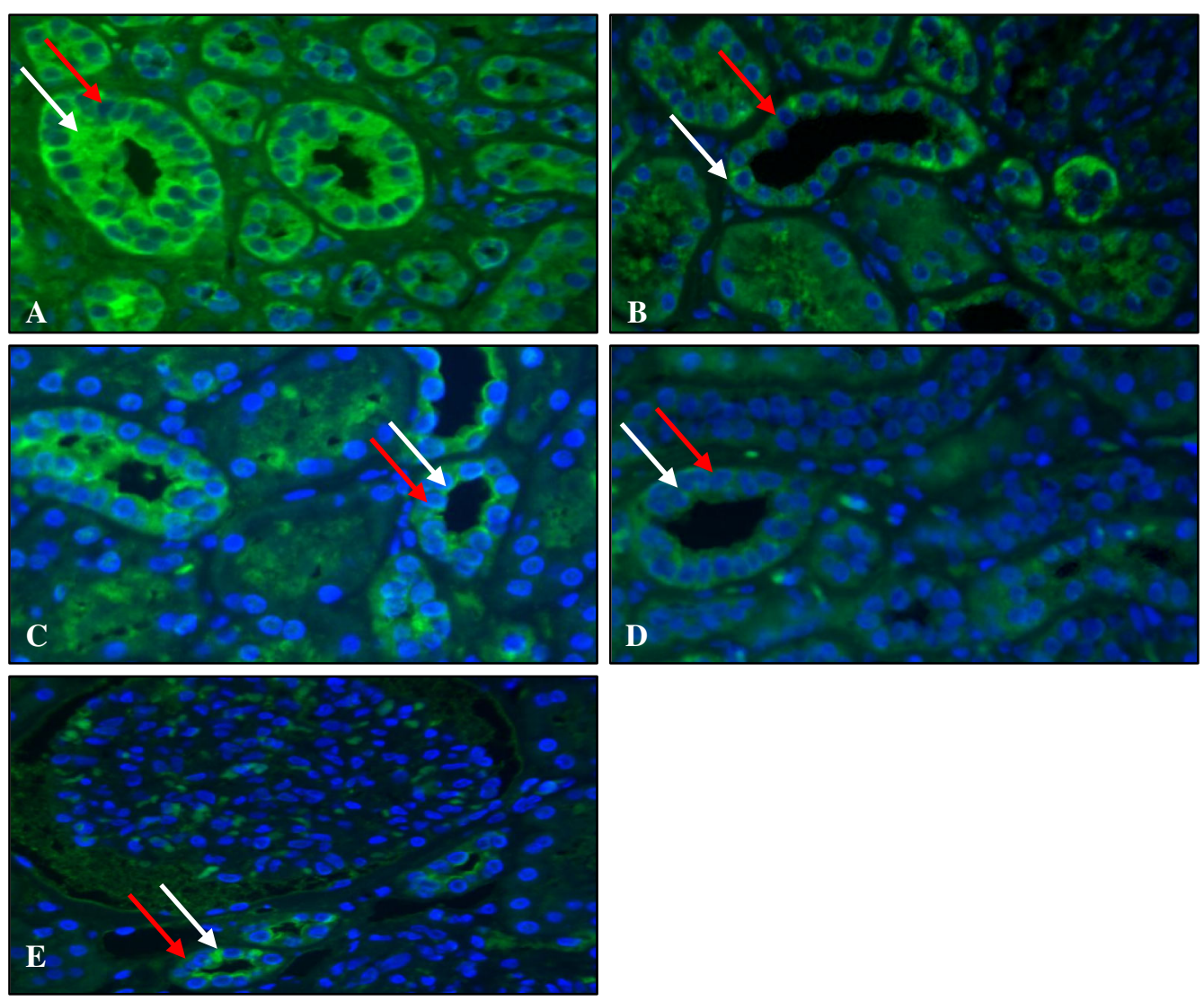

Fig. 5 Double immunofluorescence of normal kidney. UCN3 localization (green; white arrows) in cytoplasm of renal epithelial cells and nuclear counterstaining with DAPI (blue; red arrows)

grading, and advanced disease were not statistically significant as well $(p>0.05$; data not shown) (Fig. 6).

\section{DISCUSSION}

Here and for the first time a kidney cancerspecific downregulation of UCN3, which is a selective CRHR2 agonist [2], was demonstrated using the example of the two most common histological subtypes-ccRCC and pRCC. UCN3 mRNA was significantly downregulated in comparison to adjacent normal renal tissue. Expression loss of UCN3 showed no correlation with clinicopathological parameters of this cohort. The UCN3 protein was located in renal tubular cells of normal kidneys, particularly in distal tubules, whereas no immunohistochemical signals were detected in ccRCC.
Various studies have shown that members of the CRH peptide family are regulated and presented differently in a large number of human cancer entities $[5,12,14]$. Recently, we demonstrated that CRHR2, which is the only receptor known to match UCN3 [2], is not available in the vasculature of ccRCC [5]. Those findings were in accordance with recent knowledge from in vivo and in vitro studies showing that activation of CRHR2 suppresses the neovascularization through reduction of vascular endothelial growth factor (VEGF) production in an upstream regulatory way $[8,10,11]$. Excessive expression of VEGF and VEGF receptors in ccRCC has been reported frequently, which is in accordance with its histological architecture. Furthermore, a significant positive correlation between higher expression of VEGF and advanced disease stages 

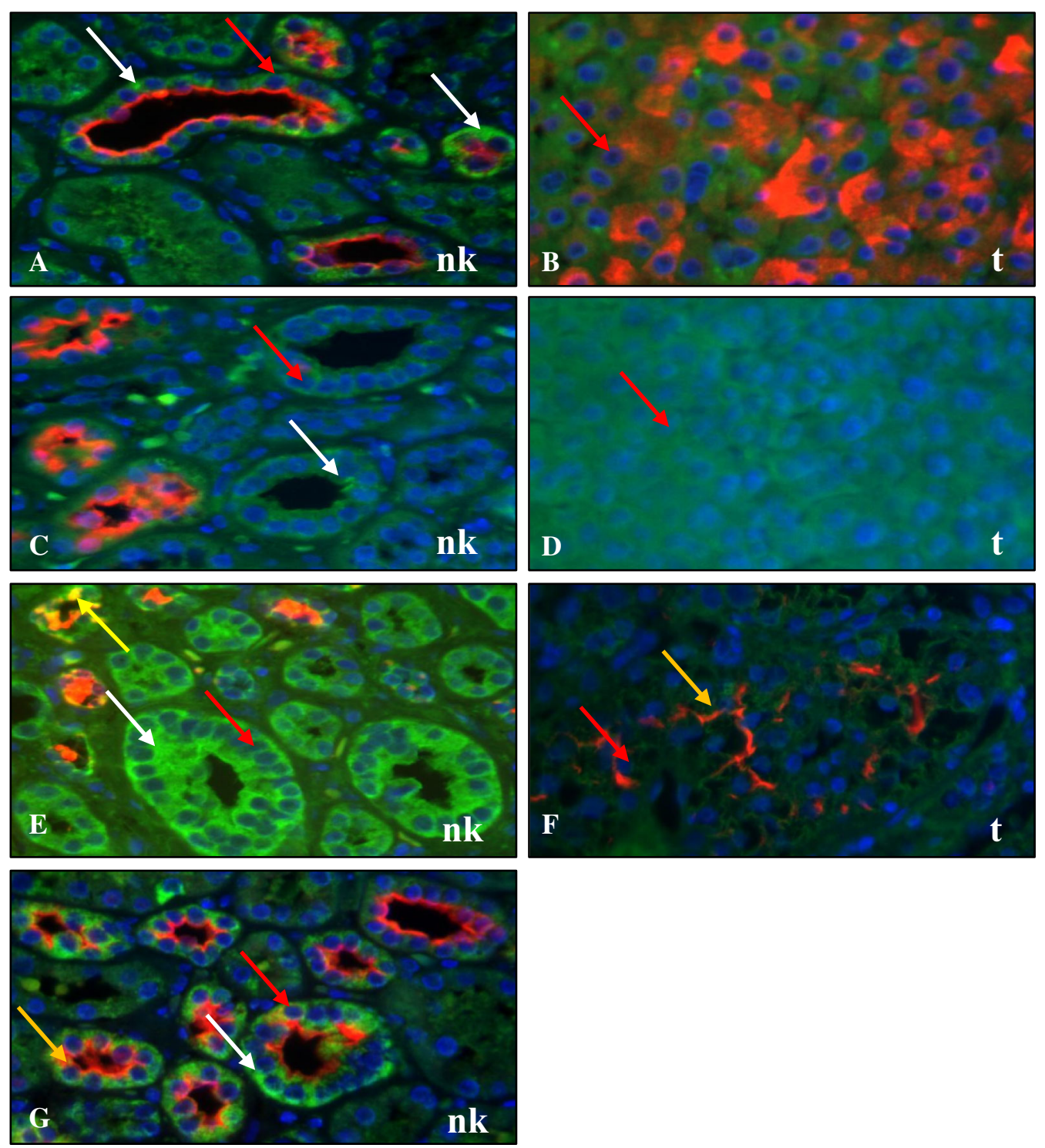

Fig. 6 Immunofluorescence of normal kidney (nk) and $\operatorname{ccRCC}(\mathfrak{t})$. UCN3 immuno-signals (white arrows) in normal kidney (a, c, e, g) and lack of immuno-positivity in $\operatorname{ccRCC}(\mathbf{b}, \mathbf{d}, \mathbf{f})$. Nuclear counterstaining (blue; red

of RCC (pT3-4 and/or $\mathrm{N}+/ \mathrm{M}+$ ) was observed [18].

Hsu and Hsueh introduced UCN3 as a CRHR2-selective agonist with no affinity to CRHR1 and were the first to show its mRNA expression in human kidney [2]. Later, Takahashi et al. succeeded in detecting the UCN3 protein in normal human kidney, plasma, and urine [4]. Presence of UCN3 in plasma and its arrows) with DAPI. MUC-1 served as marker protein for epithelial cells of distal tubules (orange; orange arrows) and CD10 was used as marker protein for epithelial cells of proximal tubules (yellow; yellow arrows)

higher level in urine prove a regulatory role for this peptide in tubular reabsorption and renal circulation. It presumes that this peptide may have a role as a circulating factor in humans [4].

A concomitant loss at genetic, protein, and immunohistochemical levels, which were demonstrated in the present study, and the disruption of CRHR2 in ccRCC, which was observed by our group lately [5], corresponds to 
the angiogenic nature of ccRCC known as a hypervascularized tumor-and to the inhibitory function of UCN3 in neovascularization through activation of CRHR2. Moreover, and as described before, activation of CRHR2 by its agonists inhibits the malignant cell proliferation in kidney cancer and other malignancies as well [8-10]. Wang et al. inhibited growth of hepatocellular carcinoma by suppressing angiogenesis via UCN/CRHR2 activation in its vessels. Use of a CRHR2 antagonist reversed angiogenesis inhibition. Consequently, the role of CRHR2 in angiogenesis was strengthened and confirmed [11]. However, in inflammatory vasculature Im et al. propagated diverging effects of CRHR1 and CRHR2 on intestinal angiogenesis. While CRH/CRHR1 promoted inflammatory vascular growth, UCN3/CRHR2 prevented these processes $[19,20]$. The extent to which these results can be directly transferred to the tumor biology of carcinomas still needs to be investigated. Several causal relationships have already been reported: Grivennikov et al. reviewed the interaction between inflammation and tumor and reported its critical role in carcinogenesis [21]. Anand et al. confirmed that most tumors are caused or promoted mainly by lifestyle habits and environment; in the overall context, only a small proportion of tumors are linked to hereditary mutations [22]. These lifestyle factors include smoking, nutrition [23], obesity [24], infection [25], and environment [26]. Aggarwal et al. identified chronic inflammation as a common characteristic of all these factors [27]. Especially smoking and obesity, which can also maintain chronic inflammation, have been identified in numerous studies as risk factors for the development of renal cancer and have therefore been included as major risk factors in the German and European guidelines for renal cancer [28-40]. A connection between inflammation and the development of cancer, also in the case of renal cancer, seems to be obvious, especially since the molecular mechanisms that apparently promote or prevent tumor development also maintain or prevent chronic inflammations, in this case various members of the $\mathrm{CRH}$ system. Recently, a significantly higher expression of $C R H$ and CRHR1 mRNA was detected in human colon cancer cell lines compared to an immortalized colonic epithelial line [41]. Fang et al. linked their results to the known involvement of CRH in inflammation by promoting VEGF and other cytokines via CRHR1 activation [42-44] and proclaimed a critical role for the CRH/CRHR1 signaling pathway in cell proliferation and tumorigenesis of human colon cancer [41]. Interestingly, there was a significantly lower mRNA expression of $U C N$ in all three tumor cell lines compared to the normal tissue tested, although immunohistochemically a higher staining of UCN in tumorous tissue compared to normal and peritumoral tissue was detected as well [41]. It is known that CRH binds to CRHR1 with an affinity that is approximately 20-fold higher than that of CRHR2 [41, 45, 46]. In contrast, UCN's receptor affinity is distributed equally between CRHR1 and CRHR2 [1, 47-49]. To what extent there is a difference, whether CRH or UCN binds to CRHR1, and what role CRHBP, which may act as a key regulator and is possibly involved in post-translational and post-secretional modifications or even subcellular translocation of these ligands, remains to be investigated $[5-7,50,51]$.

In carcinogenesis of ccRCC, a disturbance of the CRH system may occur at receptor and ligand levels, which has been shown in the present study by downregulation of UCN3 mRNA and its corresponding protein signal loss in ccRCC - and by the disruption of its receptor CRHR2, which was shown in our previous studies [5]. The point at which these changes contribute to the promotion of tumor metabolism is not yet known.

Members of the CRH peptide family have been detected in human blood and urine [4]. A significant lower UCN3 level in urine or blood serum compared to physiological levels might serve as a potential biomarker for early diagnosis of RCC, especially when radiological differentiation to benign renal tissue is critical and biopsy takings, e.g., via surgical or interventional approach, due to patients' health conditions are limited. So far, its involvement in tumor progression according to the correlation analysis in the present study, where there was no correlation between UCN3 mRNA expression level and clinicopathological parameters, seems 
to be of lesser significance. This, in turn, could be an indication of its involvement in tumorigenesis and emphasize its use as a potential biomarker for screening and early diagnosis in contrast to our last results, where a negative correlation between CRHBP mRNA levels in RCC and clinicopathological parametersmeaning tumor progression-such as advanced, metastasized, and higher stages of RCC was observed [14]. Recently, a statistical association between hypermethylation of CRHBP in RCC and more aggressive tumors was detected [52]. These epigenetic changes may influence the functional presence of CRHBP and could consecutively alter the receptor effects of CRHR1 and its corresponding ligands CRH and UCN. Thus, interactions on epigenetic levels, e.g., by epigenetic silencing of CRHBP, may also be involved in the carcinogenesis of RCC [52]. It suggests that different members of the CRH system may act at specific points in the tumor biology of RCC. While some of the peptides are more involved in tumorigenesis, others seem to play remarkable roles in the progression of the disease. Of course, confirmatory studies are necessary to support this hypothesis. In the present study and for the first time, cancerspecific losses of UCN3 mRNA levels and UCN3 protein signals in RCC were demonstrated. These findings support the hypothesis of the involvement of UCN3 in neovascularization and promotion of renal cancer. A re-induction of CRHR2-already mentioned in our previous studies [5] - and an additional re-induction of the corresponding ligand UCN3, which-based on the now available results of the present study-is nearly lost in ccRCC, could be a possible therapeutic approach in the suppression of vascularization in ccRCC. In Lewis lung carcinoma (LLC) cells these tumor-suppressing effects have already been observed. UCN2/ CRHR2 suppressed tumor vascularization and direct cell proliferation [10]. Another translational link by comparison of UCN3 urine and blood levels of patients with questionable malignancy of renal tumors and confirmed histopathological diagnosis of RCC is of further interest and will be tested soon.

\section{CONCLUSION}

Our data demonstrated a significant UCN3 mRNA downregulation and protein loss in ccRCC compared to corresponding normal renal tissue. As a naturally occurring selective CRHR2 agonist it contributes to the suppression of neovascularization by activating its corresponding receptor CRHR2. A dysfunction of the UCN3/CRHR2 system may be involved in tumorigenesis and/or disease progression and enhances the knowledge of the already shown involvement of the CRH peptide family in the biology of RCC.

\section{ACKNOWLEDGEMENTS}

We gratefully thank Ms. M. Hepke for her technical support.

Funding. No funding or sponsorship was received for this study or publication of this article.

Authorship. All named authors meet the International Committee of Medical Journal Editors (ICMJE) criteria for authorship for this article, take responsibility for the integrity of the work as a whole, and have given their approval for this version to be published.

Authorship Contributions. PFT contributed to manuscript writing/editing, data analysis and protocol/project development. AMT contributed to manuscript writing/editing, data analysis, data collection/management and protocol/project development. IP contributed to data collection/management (image editing). FA contributed to data analysis (experiments/ RNA isolation). MAK contributed to protocol/ project development (consultant). JS contributed to protocol/project development, manuscript writing/editing, data analysis and data collection/management. HT was the project leader and contributed to protocol/project development, manuscript writing/editing, data analysis and data collection/management. 
Disclosures. Pouriya Faraj Tabrizi, Anahit Mohebbi Tafrechi, Inga Peters, Faranaz Atschekzei, Markus Antonius Kuczyk, Jürgen Serth and Hossein Tezval have nothing to disclose.

Compliance with Ethics Guidelines. The study was approved by the ethical committee of the Eberhard Karls University of Tuebingen (ethics votes number 128/2003 V). All procedures performed in this study involving human participants were in accordance with the ethical standards of the institutional research committee and with the 1964 Helsinki declaration and its later amendments. Informed consent was obtained from all individual participants included in this study.

Open Access. This article is distributed under the terms of the Creative Commons Attribution-NonCommercial 4.0 International License (http://creativecommons.org/licenses/ by-nc/4.0/), which permits any noncommercial use, distribution, and reproduction in any medium, provided you give appropriate credit to the original author(s) and the source, provide a link to the Creative Commons license, and indicate if changes were made.

\section{REFERENCES}

1. Vaughan J, Donaldson C, Bittencourt J, et al. Urocortin, a mammalian neuropeptide related to fish urotensin I and to corticotropin-releasing factor. Nature. 1995;378(6554):287-92.

2. Hsu SY, Hsueh AJ. Human stresscopin and stresscopin-related peptide are selective ligands for the type 2 corticotropin-releasing hormone receptor. Nat Med. 2001;7(5):605-11.

3. Jahn O, Tezval H, van Werven L, Eckart K, Spiess J. Three-amino acid motifs of urocortin II and III determine their CRF receptor subtype selectivity. Neuropharmacology. 2004;47(2):233-42.

4. Takahashi $\mathrm{K}$, Totsune $\mathrm{K}$, Murakami $\mathrm{O}$, et al. Expression of urocortin III/stresscopin in human heart and kidney. J Clin Endocrinol Metab. 2004;89(4):1897-903.
5. Tezval H, Jurk S, Atschekzei F, et al. Urocortin and corticotropin-releasing factor receptor 2 in human renal cell carcinoma: disruption of an endogenous inhibitor of angiogenesis and proliferation. World J Urol. 2009;27(6):825-30.

6. Jahn O, Radulovic J, Stiedl O, Tezval H, Eckart K, Spiess J. Corticotropin-releasing factor binding protein-a ligand trap? Mini Rev Med Chem. 2005;5(10):953-60.

7. Behan DP, De Souza EB, Lowry PJ, Potter E, Sawchenko P, Vale WW. Corticotropin releasing factor (CRF) binding protein: a novel regulator of CRF and related peptides. Front Neuroendocrinol. 1995;16(4): 362-82.

8. Bale TL, Giordano FJ, Hickey RP, et al. Corticotropin-releasing factor receptor 2 is a tonic suppressor of vascularization. Proc Natl Acad Sci USA. 2002;99(11):7734-9.

9. Graziani G, Tentori L, Portarena I, et al. CRH inhibits cell growth of human endometrial adenocarcinoma cells via CRH-receptor 1-mediated activation of cAMP-PKA pathway. Endocrinology. 2002;143(3):807-13.

10. Hao Z, Huang Y, Cleman J, et al. Urocortin2 inhibits tumor growth via effects on vascularization and cell proliferation. Proc Natl Acad Sci USA. 2008;105(10):3939-44.

11. Wang J, Xu Y, Xu Y, et al. Urocortin's inhibition of tumor growth and angiogenesis in hepatocellular carcinoma via corticotrophin-releasing factor receptor 2. Cancer Invest. 2008;26(4):359-68.

12. Kaprara A, Pazaitou-Panayiotou K, Kortsaris A, Chatzaki E. The corticotropin releasing factor system in cancer: expression and pathophysiological implications. Cell Mol Life Sci. 2010;67(8): 1293-306.

13. Tezval H, Merseburger AS, Matuschek I, Machtens S, Kuczyk MA, Serth J. RASSF1A protein expression and correlation with clinicopathological parameters in renal cell carcinoma. BMC Urol. 2008;8:12.

14. Tezval H, Atschekzei F, Peters I, et al. Reduced mRNA expression level of corticotropin-releasing hormone-binding protein is associated with aggressive human kidney cancer. BMC Cancer. 2013;13:199.

15. Waalkes S, Atschekzei F, Kramer MW, et al. Fibronectin 1 mRNA expression correlates with advanced disease in renal cancer. BMC Cancer. 2010;10:503.

16. Livak KJ, Schmittgen TD. Analysis of relative gene expression data using real-time quantitative PCR 
and the 2(-Delta Delta $\mathrm{C}(\mathrm{T}))$ method. Methods. 2001;25(4):402-8.

17. Schmittgen TD, Livak KJ. Analyzing real-time PCR data by the comparative C(T) method. Nat Protoc. 2008;3(6):1101-8.

18. Liang Y-X, He H-C, Han Z-D, et al. CD147 and VEGF expression in advanced renal cell carcinoma and their prognostic value. Cancer Invest. 2009;27(7): 788-93.

19. Im E. Corticotropin-releasing hormone and its biological diversity toward angiogenesis. Intest Res. 2014;12(2):96-102.

20. Im E, Rhee SH, Park YS, Fiocchi C, Taché Y, Pothoulakis C. Corticotropin-releasing hormone family of peptides regulates intestinal angiogenesis. Gastroenterology. 2010;138(7):2457-67.

21. Grivennikov SI, Greten FR, Karin M. Immunity, inflammation, and cancer. Cell. 2010;140(6): 883-99.

22. Anand $\mathrm{P}$, Kunnumakkara $\mathrm{AB}$, Kunnumakara $\mathrm{AB}$, et al. Cancer is a preventable disease that requires major lifestyle changes. Pharm Res. 2008;25(9):2097-116.

23. Doll R, Peto R. The causes of cancer: quantitative estimates of avoidable risks of cancer in the United States today. J Natl Cancer Inst. 1981;66(6): 1191-308.

24. Calle EE, Rodriguez C, Walker-Thurmond K, Thun MJ. Overweight, obesity, and mortality from cancer in a prospectively studied cohort of US adults. N Engl J Med. 2003;348(17):1625-38.

25. Parkin DM. The global health burden of infectionassociated cancers in the year 2002. Int J Cancer. 2006;118(12):3030-44.

26. Belpomme D, Irigaray P, Hardell L, et al. The multitude and diversity of environmental carcinogens. Environ Res. 2007;105(3):414-29.

27. Aggarwal BB, Vijayalekshmi RV, Sung B. Targeting inflammatory pathways for prevention and therapy of cancer: short-term friend, long-term foe. Clin Cancer Res. 2009;15(2):425-30.

28. Onkologie L. S3-Leitlinie Diagnostik, Therapie und Nachsorge des Nierenzellkarzinoms. Awmf. 2017;1:1-219.

29. Ljungberg B, Bensalah K, Bex A, et al. EAU guidelines on renal cell carcinoma. Eur Assoc Urol. 2016;1:1-62.
30. Bergström A, Hsieh CC, Lindblad P, Lu CM, Cook NR, Wolk A. Obesity and renal cell cancer-a quantitative review. $\mathrm{Br} \mathrm{J}$ Cancer. 2001;85(7): 984-90.

31. Hunt JD, van der Hel OL, McMillan GP, Boffetta P, Brennan P. Renal cell carcinoma in relation to cigarette smoking: meta-analysis of 24 studies. Int J Cancer. 2005;114(1):101-8.

32. Theis RP, Dolwick Grieb SM, Burr D, Siddiqui T, Asal NR. Smoking, environmental tobacco smoke, and risk of renal cell cancer: a population-based case-control study. BMC Cancer. 2008;8:387.

33. Hu J, Ugnat A-M, Canadian Cancer Registries Epidemiology Research Group. Active and passive smoking and risk of renal cell carcinoma in Canada. Eur J Cancer. 2005;41(5):770-8.

34. Kreiger N, Marrett LD, Dodds L, Hilditch S, Darlington GA. Risk factors for renal cell carcinoma: results of a population-based case-control study. Cancer Causes Control. 1993;4(2):101-10.

35. Parker AS, Cerhan JR, Janney CA, Lynch CF, Cantor KP. Smoking cessation and renal cell carcinoma. Ann Epidemiol. 2003;13(4):245-51.

36. Renehan AG, Tyson M, Egger M, Heller RF, Zwahlen M. Body-mass index and incidence of cancer: a systematic review and meta-analysis of prospective observational studies. Lancet. 2008;371(9612):569_ 78.

37. Adams KF, Leitzmann MF, Albanes D, et al. Body size and renal cell cancer incidence in a large US cohort study. Am J Epidemiol. 2008;168(3):268-77.

38. Luo J, Margolis KL, Adami H-O, et al. Body size, weight cycling, and risk of renal cell carcinoma among postmenopausal women: the Women's Health Initiative (United States). Am J Epidemiol. 2007;166(7):752-9.

39. Nicodemus KK, Sweeney C, Folsom AR. Evaluation of dietary, medical and lifestyle risk factors for incident kidney cancer in postmenopausal women. Int J Cancer. 2004;108(1):115-21.

40. Pischon T, Lahmann PH, Boeing H, et al. Body size and risk of renal cell carcinoma in the European Prospective Investigation into Cancer and Nutrition (EPIC). Int J Cancer. 2006;118(3):728-38.

41. Fang X, Hong Y, Dai L, et al. CRH promotes human colon cancer cell proliferation via IL-6/JAK2/STAT3 signaling pathway and VEGF-induced tumor angiogenesis. Mol Carcinog. 2017;56(11):2434-45. 
42. Quintanar JL, Guzmán-Soto I. Hypothalamic neurohormones and immune responses. Front Integr Neurosci. 2013;7:56.

43. Alysandratos K-D, Asadi S, Angelidou A, et al. Neurotensin and CRH interactions augment human mast cell activation. PLoS One. 2012;7(11):e48934.

44. Webster EL, Barrientos RM, Contoreggi C, et al. Corticotropin releasing hormone $(\mathrm{CRH})$ antagonist attenuates adjuvant induced arthritis: role of $\mathrm{CRH}$ in peripheral inflammation. J Rheumatol. 2002;29(6):1252-61.

45. Perrin $\mathrm{MH}$, Vale WW. Corticotropin releasing factor receptors and their ligand family. Ann N Y Acad Sci. 1999;885:312-28.

46. Orth DN. Corticotropin-releasing hormone in humans. Endocr Rev. 1992;13(2):164-91.

47. Vale W, Spiess J, Rivier C, Rivier J. Characterization of a 41-residue ovine hypothalamic peptide that stimulates secretion of corticotropin and beta-endorphin. Science. 1981;213(4514):1394-7.
48. Grigoriadis DE, Lovenberg TW, Chalmers DT, Liaw C, De Souze EB. Characterization of corticotropinreleasing factor receptor subtypes. Ann N Y Acad Sci. 1996;780:60-80.

49. Pergialiotis V, Tagkou NM, Tsimpiktsioglou A, Klavdianou O, Neonaki A, Trompoukis P. Urocortin expression in endometriosis: a systematic review. Int J Fertil Steril. 2019;13(1):1-5.

50. Kemp CF, Woods RJ, Lowry PJ. The corticotrophinreleasing factor-binding protein: an act of several parts. Peptides. 1998;19(6):1119-28.

51. Potter E, Behan DP, Fischer WH, Linton EA, Lowry PJ, Vale WW. Cloning and characterization of the cDNAs for human and rat corticotropin releasing factor-binding proteins. Nature. 1991;349(6308): 423-6.

52. Tezval H, Dubrowinskaja N, Peters I, et al. Tumor specific epigenetic silencing of corticotropin releasing hormone-binding protein in renal cell carcinoma: association of hypermethylation and metastasis. PLoS One. 2016;11(10):e0163873. 